\title{
China's human resources for maternal and child health: a national sampling survey
}

\author{
Zhenghong Ren ${ }^{1 \dagger}$, Peige Song ${ }^{1 \dagger}$, Evropi Theodoratou ${ }^{2}$, Sufang Guo ${ }^{3}$ and Lin $\mathrm{An}^{1 *}$
}

\begin{abstract}
Background: In order to achieve the Millennium Development Goals (MDG) 4 and 5, the Chinese Government has invested greatly in improving maternal and child health $(\mathrm{MCH})$ with impressive results. However, one of the most important barriers for further improvement is the uneven distribution of MCH human resources. There is little information about the distribution, quantity and capacity of the Chinese $\mathrm{MCH}$ human resources and we sought to investigate this.

Methods: Cities at prefectural level were selected by random cluster sampling. All medical and health institutions providing $\mathrm{MCH}$-related services in the sampled areas were investigated using a structured questionnaire. The data were weighted based on the proportion of the sampled districts/cities. Amount, proportions and numbers per 10,000 population of MCH human resources were estimated in order to reveal the quantity of the Chinese $\mathrm{MCH}$ human resources. The capacity of $\mathrm{MCH}$ human resources was evaluated by analyzing data on the education level and professional skills of the staff.

Results: There were 77,248 MCH workers in our investigated institutions in 2010. In general, $67.6 \%$ and $71.9 \%$ of the women's and children's health care professionals had an associate degree or higher, whereas around $30 \%$ had only high-school or lower degrees. More than $40 \%$ of the women's health workers were capable of providing skilled birth attendance, but these proportions varied between different institutions and locations.

Conclusions: Evidence from this study highlights that Chinese $\mathrm{MCH}$ human resources are not in shortage in the national level. However, the quantity and capacity of $\mathrm{MCH}$ human resources are not evenly distributed among different institutions and locations. Finally there is a need in the improvement of the $\mathrm{MCH}$ services by improving the quality of $\mathrm{MCH}$ human resources.
\end{abstract}

Keywords: Maternal and child health, Human resources, China

\section{Background}

Health of women and children is the main foundation of sustained human development and a high priority for the international community $[1,2]$. In 2000,189 member states of United Nations adopted the Millennium Declaration committing to achieve 8 Millennium Development Goals (MDGs), aiming to accelerate development and to reduce poverty. Of these goals, two are directly related to maternal and child health: MDG 4 (a two-thirds reduction in under- 5 mortality between 1990 and 2015) and MDG 5 (a three-quarters reduction in

\footnotetext{
* Correspondence: anlinbjmu@163.com

${ }^{\dagger}$ Equal contributors

'Department of Child, Adolescent and Women's Health, School of Public Health, Peking University, Beijing, China

Full list of author information is available at the end of the article
}

maternal mortality ratio between 1990 and 2015) [3]. Since then, a number of efforts have been taken to globally reduce child mortality and to improve maternal health. One such effort is the "Countdown to 2015" project, a global initiative that began in 2003 to track progress in maternal, newborn and child health in the 75 highest burden countries and to promote action and accountability [4].

In addition to these international efforts, there are several domestic initiatives. The Chinese Government has invested greatly in improving maternal and child health $(\mathrm{MCH})$ by promoting institutional delivery and implementing public $\mathrm{MCH}$ service programs [5]. One of these programs is a national program called "Reduce Maternal Mortality and Eliminate Neonatal Tetanus", which was 
implemented in 2000 and provided obstetric equipment for hospitals and training of medical staff. In the end of 2011 , this program reached a coverage of 2,297 counties (80.5\% of total) and of around 830 million people (60.6 \% of total) [1]. Additional national efforts include the implementation of a national healthcare system for women by increasing governmental financial input and by incorporating maternity insurance into the social security system [6]. In the past decade, the proportion of mothers who have had five or more antenatal visits during pregnancy increased from $43.2 \%$ in 2003 to $62.8 \%$ in 2011, and institutional delivery rates rose from $73.3 \%$ in 2003 to $95.8 \%$ in 2011, all of which indicate a big acceleration in promoting $\mathrm{MCH}$ in an effort to reduce maternal and child mortality [7].

China has been considered as one of the countries that are set to achieve both MDGs 4 and 5 by $2015[8,9]$. In particular, the under- 5 mortality reduced from 45.7 and 13.8 (per 1000 live births) in rural and urban areas in 2000 to 19.1 and 7.1 in 2011 , and the maternal mortality reduced from 69.6 and 29.3 (per 100,000 live births) in rural and urban areas in 2000 to 26.5 and 25.2 in 2011. However, inequalities in $\mathrm{MCH}$ between urban and rural areas, between different regions and between different population groups still exist and the overall development of $\mathrm{MCH}$ service network is lagging behind [1].

Health human resources refer to all professionals engaged in health works, which normally include physicians, nurses and midwives, as well as dentists and pharmacists, laboratory technicians, etc. [10, 11]. Estimation of the human resources can help to identify the constraints and the potential impacts on population health. Valid MCH human resources analysis can also be used as a tool for policy making when managing and delivering $\mathrm{MCH}$ health services [12].

In China, $\mathrm{MCH}$ was categorized as a specific area where women and children can receive specialized all-round curative and preventive healthcare by health professionals from general hospitals, $\mathrm{MCH}$ institutions and community-based healthcare services at province, prefectural, county, township and village level $[1,13]$, In addition, there are also some auxiliary $\mathrm{MCH}$ workers, including specific $\mathrm{MCH}$ health education staff and $\mathrm{MCH}$ annual report statisticians, the common point of these $\mathrm{MCH}$ workers is their working contents, which only focus on $\mathrm{MCH}$ [14]. In order to learn the situation of $\mathrm{MCH}$ human resources in China, a national survey on MCH human resources was conducted in 2011 and in this study we analyzed the numbers, distribution and capacity of the $\mathrm{MCH}$ human resources.

\section{Methods}

\section{The $\mathrm{MCH}$ human resources}

In China, health workers should hold health qualification certificates, even for health workers who providing auxiliary health services, such as management and statistics when they work in health institutions [15]. In this study, the $\mathrm{MCH}$ human resources were defined as workers who 1) provide $\mathrm{MCH}$-related services and 2) hold at least one legal health qualification certificate. All other workers were excluded.

In this study, $\mathrm{MCH}$-related services include:

1) Women's health: female adolescent health care, female pre-marital health care, preconception care, basic obstetric care, emergency obstetric care, maternal health care, postpartum health care, menopause and elderly health care, women's mental health care, women's nutrition and general gynecological diseases screening.

2) Children's health: basic pediatric health care, neonatal emergency care, neonatal disease screening, newborn hearing screening, breastfeeding guidance, growth and nutritional care, mental health care, oral health care, hearing health care, eye health care, children's intellectual development inspection, children physical examination, children rehabilitation.

3) $\mathrm{MCH}$ health education: preparing $\mathrm{MCH}$ health educational materials, community and institutionbased health education, matrimony health education and pregnancy education.

4) $\mathrm{MCH}$ training and supervision: supervision and training of junior staff and medical students.

5) $\mathrm{MCH}$ management: monitoring the quality of $\mathrm{MCH}$ work; management and monitoring of $\mathrm{MCH}$ health related archives.

6) $\mathrm{MCH}$ related research projects: international and domestic special projects on $\mathrm{MCH}$.

7) $\mathrm{MCH}$ statistics: monitoring, collecting and analyzing $\mathrm{MCH}$ information for annual reports; reporting the annual report quality control results; maternal, child mortality assessment.

\section{Sampling of the MCH-related institutions}

The Chinese Government has established a hierarchical administrative network for $\mathrm{MCH}$, which can provide a full range of healthcare services covering the entire health care services spectrum for women and children [1]. The top-down sequence is province level, prefectural level, county level, township level and village level [13]. In this study, we chose cities in prefectural level as the sampling unit level since the sampling size at a higher level (province level) would not have been enough, whereas sampling at prefectural level can cover all levels and types of medical and health care institutions providing $\mathrm{MCH}$ services. This study is a national institutionbased sampling survey with formal approval from both the national maternal and child health annual report office and the National Health and Family Planning 
Commission of the People's Republic of China (the former Chinese Ministry of Health) $[16,17]$. All data was anonymized and we were granted permission to use and analyze the data by all the participating institutions.

For the 22 provinces and 5 autonomous regions in China, 28 prefectural-level districts/cities were selected out of all the 332 municipality prefectural districts/cities by random cluster sampling. Then, for the four municipalities (Beijing, Shanghai, Tianjin and Chongqing) in China, two urban districts and two rural counties were drawn respectively by random cluster sampling. Finally, all the selected districts/cities covered all province level administrative divisions in China except for Tibet autonomous region, Hainan province (there are only a few cities) and the two special administrative regions (Hong Kong and Macau), the distribution of the sampled districts/cities is shown in Fig. 1. Then all randomly selected districts/cities were treated as clusters and all the medical and health care institutions providing $\mathrm{MCH}$ services were selected as our targeted institutions.

\section{Procedures}

A structured questionnaire, which was developed and improved by several rounds of expert consultation and then piloted in a study, was used in this institutionbased survey. Questions on $\mathrm{MCH}$ human resources were mainly about the demographic characteristics, the amount and types of provided services and the education level and skills of the health professionals; Questions on $\mathrm{MCH}$-related institutions were mainly about the type and location of the institution. The questionnaires were sent to the institutions by post with assistance of local health administrative departments. Then they were completed by the institutions' heads under the supervision of their local technicians, who had already received training in Beijing (especially in relation to classification of the different service types). Questionnaires were then sent back to the research group directly. Finally, we received all the data from every health institution, and the participating institution heads granted us permission to use the data, all the data was anonymized and none of the researchers could identify any personal information.

\section{Statistical analysis}

Data were weighted based on the proportion of sampled districts/cities. The weights were 4 for Beijing and Tianjin, 4.5 for Shanghai, 10 for Chongqing and 11 for all other cities (see Appendix 1 for more details). By using the weights, the numbers of the weighted populations (permanent resident population) in the sampled districts/cities were very near ( $5.7 \%$ error) to the actual census populations in 2010. Then data were grouped into three geographic regions: east, central and west, which are defined by the Chinese Government and roughly represent different levels of economic development. East region areas are

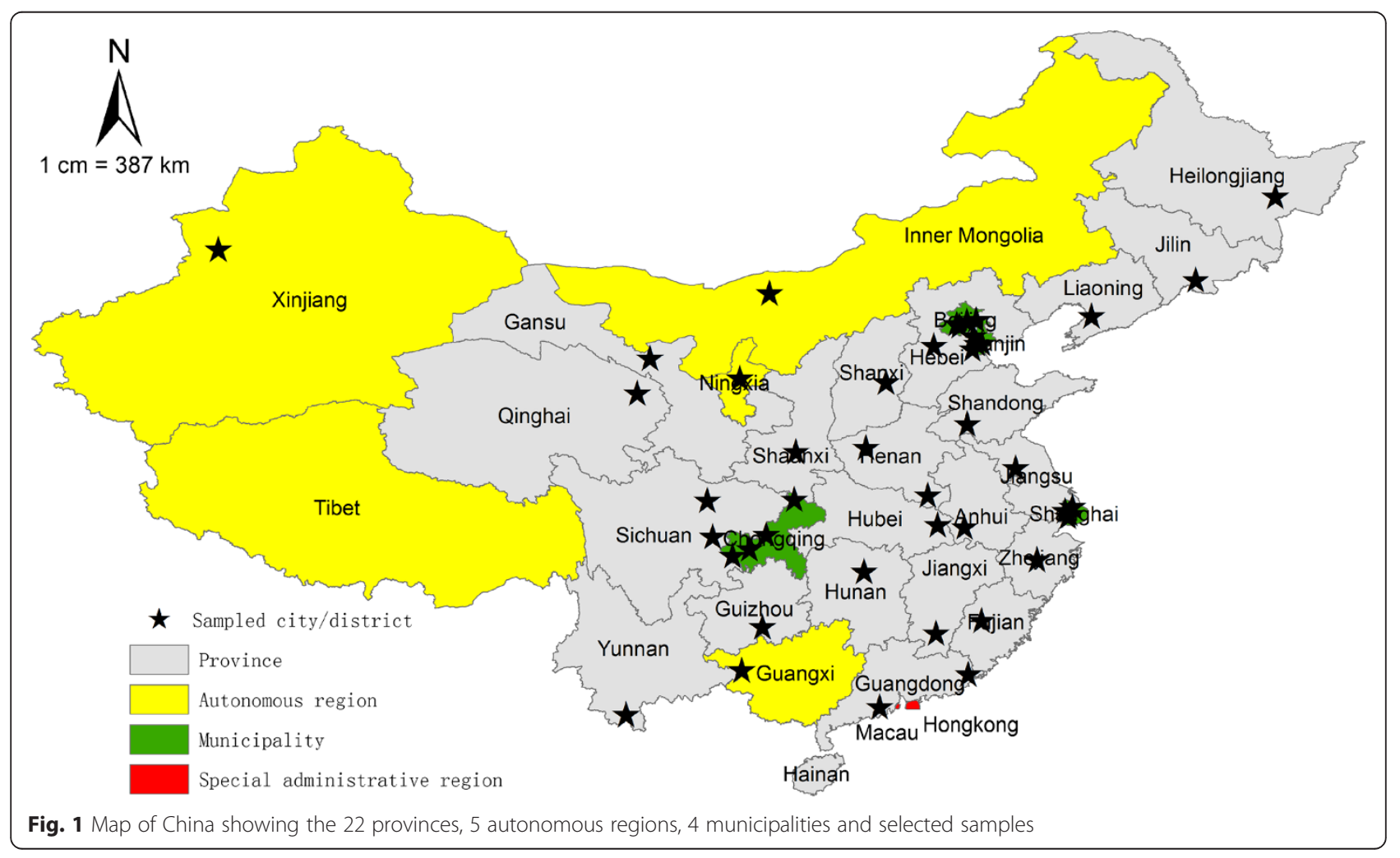


Table 1 Percentage of female MCH workers for the different service types in the three regions

\begin{tabular}{llllllll}
\hline & \multicolumn{2}{l}{ Type of MCH work (\%) } \\
\cline { 2 - 8 } Region & Women's health & Children's health & Health education & Training and supervision & Management & Project/ research/ education & Statistics \\
\hline East & 95.2 & 77.8 & 89.7 & 87.7 & 78.6 & 86.0 & 89.2 \\
Central & 94.3 & 72.9 & 89.3 & 86.4 & 74.0 & 82.9 & 89.4 \\
West & 96.4 & 83.7 & 91.6 & 90.4 & 83.6 & 89.0 & 92.4 \\
Total & 95.2 & 78.2 & 90.2 & 88.2 & 78.7 & 86.2 & 90.4 \\
\hline
\end{tabular}

Abbreviation: $\mathrm{MCH}$ maternal and child health

the most developed, whereas the west region is the least developed. The east region includes 11 provinces: Beijing, Tianjin, Hebei, Liaoning, Shanghai, Jiangsu, Zhejiang, Fujian, Shandong, Guangdong and Hainan; the central region includes 8 provinces: Shanxi, Jilin, Heilongjiang, Anhui, Jiangxi, Henan, Hubei and Hunan; and the west region includes 12 provinces: Inner Mongolia, Guangxi, Shaanxi, Gansu, Qinghai, Ningxia, Xinjiang, Sichuan, Chongqing, Guizhou, Yunnan and Tibet [18].

When counting the number of $\mathrm{MCH}$ workers, a weight 0.5 was assigned to workers who were not working full-time in $\mathrm{MCH}$ to avoid overestimation of the total $\mathrm{MCH}$ human resources. The total number per 10,000 population and proportion of $\mathrm{MCH}$ human resources were calculated in order to reveal the overall quantity of the $\mathrm{MCH}$ human resources in China. Stratified calculations by different regions, different levels and types of health institutions were also presented. When evaluating the capacity of the $\mathrm{MCH}$ services, three proxies were chosen: \% of appropriately educated of health workers, \% of health workers that could perform cardiopulmonary resuscitation (as a proxy of common medical skill), and for women's health workforce, \% of medical staff that could perform caesarean section, forceps and vacuum extraction deliveries (as a proxy of maternal health related skill). Therefore, we only focused on the workers providing curative and preventive women and children's healthcare services in the $\mathrm{MCH}$ frontline. Other auxiliary $\mathrm{MCH}$ service (health education, training and supervision, management, project/ research/ education, statistics) providers were excluded because these services can also be effectively provided by less educated health workers.
All analyses were conducted in the software SPSS 13.0.

\section{Results}

\section{Quantity of Chinese MCH human resources}

There were $77,248 \mathrm{MCH}$ workers in the investigated 5,168 health institutions in 2010. The number of $\mathrm{MCH}$ workers per 10,000 population was 5.5 at national level, 5.7 for the east and west regions, and 5.1 for the central region. Most $\mathrm{MCH}$ workers were female (Table 1), especially for workers providing women's healthcare services (95.2 \%), health education (90.2 \%) and statistics (90.4\%). The gender distributions were similar across all regions.

$40.5 \%$ of the $\mathrm{MCH}$ workforce concentrated on women's healthcare services followed by children's curative and preventive healthcare services (25.7 \%) and $\mathrm{MCH}$ education (15.5\%; Table 2). The proportions of $\mathrm{MCH}$ workforce for other service types (training, supervision, management, research and statistical information management) were near $10 \%$.

At national level, $48.8 \%$ of the $\mathrm{MCH}$ workers were working in general hospitals (accounting for $21.4 \%$ of all health institutions) and $26.7 \%$ in specialized $\mathrm{MCH}$ institutions (5.6 \% of all health institutions). $59.4 \%$ of all health institutions were township or community health centers but only $23.0 \% \mathrm{MCH}$ workers worked there (Table 3). Higher percentages of $\mathrm{MCH}$ workers worked in general hospitals and community health centers in the east region, while the percentage of $\mathrm{MCH}$ workers in township health centers was much higher in the central region.

Most of the Chinese $\mathrm{MCH}$ workers (44.2\%; Table 4) were working in county level health institutions (accounting for $20.64 \%$ of all $\mathrm{MCH}$ institutions), and the proportions of $\mathrm{MCH}$ workers in prefectural level (5.22\%

Table 2 Service distribution of $\mathrm{MCH}$ workers in the three regions

\begin{tabular}{lllllllll}
\hline \multirow{2}{*}{ Region } & $\begin{array}{l}\text { Number of MCH human } \\
\text { resources }(\mathrm{n})\end{array}$ & $\begin{array}{l}\text { Type of MCH work }(\mathrm{n}(\%)) \\
\text { health }\end{array}$ & $\begin{array}{l}\text { Children's } \\
\text { health }\end{array}$ & $\begin{array}{l}\text { Health } \\
\text { education }\end{array}$ & $\begin{array}{l}\text { Training and } \\
\text { supervision }\end{array}$ & Management & $\begin{array}{l}\text { Project/ research/ } \\
\text { education }\end{array}$ & Statistics \\
\hline East & 296225 & $110535(37.3)$ & $63895(21.6)$ & $38882(13.1)$ & $30156(10.2)$ & $26210(8.8)$ & $21453(7.2)$ & $25448(8.6)$ \\
Central & 256426 & $112805(44.0)$ & $66759(26.0)$ & $41360(16.1)$ & $30327(11.8)$ & $26477(10.3)$ & $15818(6.2)$ & $26675(10.4)$ \\
West & 226614 & $92042(40.6)$ & $69742(30.8)$ & $40510(17.9)$ & $31123(13.7)$ & $26553(11.7)$ & $18754(8.3)$ & $26218(11.6)$ \\
Total & 779265 & $315382(40.5)$ & $200396(25.7)$ & $120752(15.5)$ & $91606(11.8)$ & $79240(10.2)$ & $56025(7.2)$ & $78341(10.1)$ \\
\hline
\end{tabular}

Abbreviation: MCH maternal and child health 
Table 3 Institutional distribution of $\mathrm{MCH}$ workers in the three regions

\begin{tabular}{|c|c|c|c|c|c|c|c|}
\hline \multirow[b]{2}{*}{ Region } & \multirow[b]{2}{*}{$\begin{array}{l}\text { Number of MCH human } \\
\text { resources (n) }\end{array}$} & \multicolumn{6}{|c|}{ Type of MCH institutions (n(\%)) } \\
\hline & & $\begin{array}{l}\text { General } \\
\text { hospital }\end{array}$ & $\begin{array}{l}\text { Specialized MCH } \\
\text { institution }\end{array}$ & $\begin{array}{l}\text { Township health } \\
\text { center }\end{array}$ & $\begin{array}{l}\text { Community health } \\
\text { center }\end{array}$ & $\begin{array}{l}\text { Family planning } \\
\text { service station }\end{array}$ & Others \\
\hline East & 296225 & $162509(54.9)$ & $74841(25.3)$ & $41374(14.0)$ & $15820(5.3)$ & $727(0.2)$ & $956(0.3)$ \\
\hline Central & 256426 & $103947(40.5)$ & $69611(27.1)$ & $64345(25.1)$ & $10724(4.2)$ & $7205(2.8)$ & $594(0.2)$ \\
\hline West & 226614 & $113604(50.1)$ & $63292(27.9)$ & $36551(16.1)$ & $10167(4.5)$ & 2530(1.1) & $470(0.2)$ \\
\hline Total & 779265 & $380059(48.8)$ & 207744(26.7) & $142270(18.3)$ & $36710(4.7)$ & $10462(1.3)$ & $2020(0.3)$ \\
\hline
\end{tabular}

Abbreviation: $\mathrm{MCH}$ maternal and child health

of all $\mathrm{MCH}$ institutions) and township level (73.19 \% of all $\mathrm{MCH}$ institutions) $\mathrm{MCH}$-related institutions were $23.4 \%$ and $24.7 \%$ respectively. Only $0.94 \%$ of the $\mathrm{MCH}$-related institutions were at provincial level and $7.7 \%$ of the total $\mathrm{MCH}$ workers were placed in these institutions. In general, $1 / 16$ of all the $\mathrm{MCH}$-related institutions were located in provincial and prefectural cities but accounted for $1 / 3$ of all the $\mathrm{MCH}$ workers. Each provincial level $\mathrm{MCH}$-related institution employed nearly $117 \mathrm{MCH}$ workers. The corresponding numbers were 64 for prefectural level and 31 for county level health institution, and only less than 5 for township level.

\section{Capacity of Chinese $\mathrm{MCH}$ human resources Education levels}

The education levels of women's and children's curative and preventive healthcare personnel are shown in Tables 5 and 6 . In general, $67.6 \%$ and $71.9 \%$ of the women's and children's health care professionals had an associate degree or higher. Only $1.6 \%$ and $2.3 \%$ of the women's and children's health care professionals had masters or higher degrees respectively. The proportion of $\mathrm{MCH}$ workers with high education level (including bachelor, master and above) was largest in the east provinces, and lowest in the central region. In general hospitals and specialized $\mathrm{MCH}$ institutions, $\mathrm{MCH}$ workers with master and higher degrees were relatively more than in other health institutions. In township health centers and community health centers, those with high level education accounted for around $40.0 \%$. The proportion of $\mathrm{MCH}$ workers with higher degrees was higher in higher level institutions, for example in the provincial level of $\mathrm{MCH}$-related institutions of the central region, more than $1 / 3$ of the $\mathrm{MCH}$ workers hold master or higher education degrees, and those with bachelor and above degrees were more than $80 \%$.

\section{Professional skills}

The proportions of women's health workers capable of caesarean section, forceps and vacuum extraction deliveries were estimated across regions, types and levels of health institutions (Table 7). In general, more than $40 \%$ of the women's health workers were capable of providing these delivery services, and those with vacuum extraction delivery skills were more than $50 \%$. The proportion of women's health workers who could provide skilled birth attendance (including caesarean section, forceps and vacuum extraction deliveries) was largest in the central region, while the east and the west had similar proportions. In terms of different types of health institutions by regions, the proportions of $\mathrm{MCH}$ workforces who could provide skilled birth attendance were highest in general hospitals for all regions. Family planning service stations were the second and specialized $\mathrm{MCH}$ institutions were the third in the east and the central regions. However, in the west region, proportions of skilled birth attendants were relatively low (less than $10 \%$ ) in the family planning stations, whereas the proportions of skilled birth attendants were similar across general hospitals and specialized $\mathrm{MCH}$ institutions. In terms of distribution by location levels of health institutions, the proportions of skilled birth attendants were similar among prefectural and county level health institutions, ranking the first, and then followed by provincial level and township level $\mathrm{MCH}$-related institutions.

Table 4 Locational distribution of MCH workers in the three regions

\begin{tabular}{|c|c|c|c|c|c|}
\hline \multirow[b]{2}{*}{ Region } & \multirow[b]{2}{*}{ Number of MCH human resources (n) } & \multicolumn{4}{|c|}{ Location level of MCH institutions (n(\%)) } \\
\hline & & Province level & Prefectural level & County level & Township level \\
\hline East & 291563 & $19751(6.8)$ & $82978(28.5)$ & $126614(43.4)$ & $62221(21.3)$ \\
\hline Central & 256349 & $3762(1.5)$ & 45994(17.9) & $126363(49.3)$ & $80230(31.3)$ \\
\hline West & 226603 & $35772(15.8)$ & $52442(23.1)$ & $89301(39.4)$ & $49088(21.7)$ \\
\hline Total & 774515 & $59285(7.7)$ & $181414(23.4)$ & $342277(44.2)$ & $191540(24.7)$ \\
\hline
\end{tabular}

Abbreviation: $\mathrm{MCH}$ maternal and child health 
Table 5 Education levels of women and children's health workers

\begin{tabular}{|c|c|c|c|c|c|c|c|c|c|}
\hline \multirow[b]{2}{*}{ Area } & \multirow[b]{2}{*}{$\begin{array}{l}\text { Type of MCH-related } \\
\text { institutions }\end{array}$} & \multicolumn{4}{|c|}{ Education level(women's health) (\%) } & \multicolumn{4}{|c|}{ Education level(children's health) (\%) } \\
\hline & & $\begin{array}{l}\text { Master and } \\
\text { above }\end{array}$ & Bachelor & Associate degree & $\begin{array}{l}\text { High school } \\
\text { and lower }\end{array}$ & $\begin{array}{l}\text { Master and } \\
\text { above }\end{array}$ & Bachelor & $\begin{array}{l}\text { Associate } \\
\text { degree }\end{array}$ & $\begin{array}{l}\text { High school } \\
\text { and below }\end{array}$ \\
\hline \multirow[t]{6}{*}{ East } & General hospital & 3.7 & 35.0 & 33.7 & 27.7 & 6.6 & 41.1 & 29.8 & 22.5 \\
\hline & Specialized MCH institution & 3.5 & 38.4 & 27.8 & 30.3 & 2.3 & 35.4 & 31.7 & 30.6 \\
\hline & $\begin{array}{l}\text { Township health center/ } \\
\text { Community health center }\end{array}$ & 0.2 & 17.6 & 42.2 & 40.0 & 0.3 & 20.1 & 41.6 & 38.0 \\
\hline & Family planning service station & 0.0 & 26.4 & 31.0 & 42.6 & 0.0 & 0.0 & 50.0 & 50.0 \\
\hline & Others & 3.0 & 45.1 & 23.9 & 28.0 & 0.0 & 65.5 & 19.6 & 14.9 \\
\hline & subtotal & 2.3 & 29.1 & 35.7 & 32.9 & 3.4 & 31.8 & 34.8 & 30.0 \\
\hline \multirow[t]{6}{*}{ Central } & General hospital & 2.0 & 29.4 & 43.1 & 25.5 & 1.5 & 36.3 & 40.3 & 21.9 \\
\hline & Specialized MCH institution & 0.1 & 23.7 & 41.2 & 35.0 & 0.2 & 28.5 & 45.5 & 25.8 \\
\hline & $\begin{array}{l}\text { Township health center/ } \\
\text { Community health center }\end{array}$ & 0.0 & 7.2 & 45.1 & 47.7 & 0.0 & 8.6 & 48.1 & 43.3 \\
\hline & Family planning service station & 0.0 & 12.0 & 54.2 & 33.9 & 0.0 & 0.0 & 60.0 & 40.0 \\
\hline & Others & 0.0 & 12.5 & 42.5 & 45.0 & 0.0 & 10.3 & 44.8 & 44.8 \\
\hline & subtotal & 0.6 & 17.5 & 44.0 & 37.8 & 0.5 & 20.3 & 45.4 & 33.8 \\
\hline \multirow[t]{6}{*}{ West } & General hospital & 3.7 & 32.9 & 45.7 & 17.8 & 4.6 & 35.8 & 44.7 & 14.9 \\
\hline & Specialized MCH institution & 0.2 & 20.0 & 48.9 & 30.9 & 0.2 & 27.8 & 46.7 & 25.3 \\
\hline & $\begin{array}{l}\text { Township health center/ } \\
\text { Community health center }\end{array}$ & 0.0 & 13.5 & 50.0 & 36.6 & 0.0 & 13.8 & 49.5 & 36.8 \\
\hline & Family planning service station & 0.0 & 22.3 & 41.7 & 35.9 & 0.0 & 37.5 & 62.5 & 0.0 \\
\hline & Others & 0.0 & 6.3 & 68.8 & 25.0 & 0.0 & 22.2 & 44.4 & 33.3 \\
\hline & Subtotal & 2.0 & 24.9 & 47.4 & 25.7 & 2.8 & 28.6 & 46.3 & 22.3 \\
\hline \multirow[t]{5}{*}{ Total } & General hospital & 3.2 & 32.7 & 40.9 & 23.1 & 4.6 & 37.4 & 39.5 & 18.4 \\
\hline & Specialized MCH institution & 1.4 & 28.2 & 38.1 & 32.4 & 0.9 & 30.4 & 41.6 & 27.1 \\
\hline & $\begin{array}{l}\text { Township health center/ } \\
\text { Community health center }\end{array}$ & 0.1 & 12.3 & 45.4 & 42.3 & 0.1 & 13.6 & 46.5 & 39.8 \\
\hline & Family planning service station & 0.0 & 16.2 & 48.5 & 35.3 & 0.0 & 17.6 & 58.8 & 23.5 \\
\hline & Others & 0.9 & 21.0 & 42.2 & 35.9 & 0.0 & 26.2 & 39.1 & 34.7 \\
\hline Total & & 1.6 & 23.7 & 42.3 & 32.3 & 2.3 & 27.0 & 42.6 & 28.2 \\
\hline
\end{tabular}

Abbreviation: $M C H$ maternal and child health

More than $80 \%$ of women and children's health workers had the capacity to perform cardiopulmonary resuscitation (Table 8). In terms of different types of health institutions, the proportions of health workers capable of cardiopulmonary resuscitations were higher than $90 \%$ in general hospitals, but were also high in specialized $\mathrm{MCH}$ institutions, township health center and community health care centers (more than $75 \%$ ). Provincial level institutions employed the highest proportions of skilled cardiopulmonary resuscitation health workers (above $95 \%$ ), followed by prefectural levels (higher than $90 \%$ ). County level and township level MCH-related institutions had similar proportions which were all above $75 \%$.

\section{Discussion}

Our study is the first nationwide $\mathrm{MCH}$ human resources investigation in China. In this study, the situation of
$\mathrm{MCH}$ human resources in 2010 was evaluated by analyzing the quantity, capacity and distribution of $\mathrm{MCH}$ workers. The health institution samples covered a large range of areas and had a relatively symmetrical distribution. The four municipalities were sampled separately, so the corresponding samples could represent the four municipal cities. But for the other areas, the sampling representativeness for each province cannot be guaranteed; therefore we cannot use the samples to estimate the $\mathrm{MCH}$ human resources in each province or autonomous district. We can however make a good assessment for the whole nation and the three regions (East, West and Central China). The samples were drawn at prefectural level and all types and location levels of health institutions providing $\mathrm{MCH}$ services in the sampled areas were investigated. To account for the sampling error when drawing samples from the prefectural level, 
Table 6 Education levels of women and children's health workers of different institutions in the three regions

\begin{tabular}{|c|c|c|c|c|c|c|c|c|c|}
\hline \multirow[b]{2}{*}{ Area } & \multirow[b]{2}{*}{$\begin{array}{l}\text { Location level of } \\
\text { MCH-related institutions }\end{array}$} & \multicolumn{4}{|c|}{ Education level(women's health) (\%) } & \multicolumn{4}{|c|}{ Education level(children's health) (\%) } \\
\hline & & Master and above & Bachelor & $\begin{array}{l}\text { Associate } \\
\text { degree }\end{array}$ & $\begin{array}{l}\text { High school } \\
\text { and lower }\end{array}$ & $\begin{array}{l}\text { Master and } \\
\text { above }\end{array}$ & Bachelor & $\begin{array}{l}\text { Associate } \\
\text { degree }\end{array}$ & $\begin{array}{l}\text { High school } \\
\text { and below }\end{array}$ \\
\hline \multirow[t]{5}{*}{ East } & Province level & 16.4 & 44.5 & 17.1 & 21.9 & 14.8 & 38.5 & 27.1 & 19.6 \\
\hline & Prefectural level & 4.5 & 41.9 & 28.3 & 25.3 & 10.9 & 42.1 & 29.9 & 17.2 \\
\hline & County level & 2.4 & 35.2 & 32.9 & 29.5 & 1.3 & 39.3 & 31.7 & 27.8 \\
\hline & Township level & 0.2 & 17.7 & 42.3 & 39.8 & 0.3 & 21.0 & 40.9 & 37.7 \\
\hline & Subtotal & 2.2 & 29.0 & 35.7 & 33.1 & 3.4 & 31.7 & 34.9 & 30.0 \\
\hline \multirow[t]{5}{*}{ Central } & Province level & 33.9 & 46.4 & 14.3 & 5.4 & 40.0 & 40.0 & 16.0 & 4.0 \\
\hline & Prefectural level & 2.5 & 41.3 & 36.6 & 19.5 & 1.5 & 45.1 & 35.2 & 18.3 \\
\hline & County level & 0.2 & 21.9 & 45.5 & 32.4 & 0.1 & 27.4 & 46.9 & 25.6 \\
\hline & Township level & 0.0 & 7.6 & 44.9 & 47.5 & 0.0 & 9.1 & 47.6 & 43.3 \\
\hline & Subtotal & 0.6 & 17.6 & 44.0 & 37.8 & 0.5 & 20.3 & 45.4 & 33.8 \\
\hline \multirow[t]{5}{*}{ West } & Province level & 7.2 & 37.3 & 43.4 & 12.1 & 6.2 & 39.5 & 44.8 & 9.5 \\
\hline & Prefectural level & 3.3 & 38.2 & 43.0 & 15.5 & 5.1 & 34.9 & 44.3 & 15.8 \\
\hline & County level & 0.4 & 22.3 & 50.0 & 27.2 & 0.2 & 30.0 & 47.4 & 22.5 \\
\hline & Township level & 0.2 & 13.3 & 49.4 & 37.1 & 0.1 & 13.8 & 48.6 & 37.5 \\
\hline & Subtotal & 2.0 & 24.9 & 47.4 & 25.7 & 2.8 & 28.6 & 46.3 & 22.3 \\
\hline \multirow[t]{4}{*}{ Total } & Province level & 9.9 & 39.0 & 37.5 & 13.6 & 9.5 & 39.2 & 38.7 & 12.6 \\
\hline & Prefectural level & 3.3 & 40.1 & 37.5 & 19.1 & 5.0 & 38.3 & 40.1 & 16.6 \\
\hline & County level & 1.1 & 27.1 & 41.8 & 29.9 & 0.6 & 32.6 & 41.3 & 25.5 \\
\hline & Township level & 0.1 & 12.5 & 45.1 & 42.3 & 0.1 & 14.1 & 45.8 & 39.9 \\
\hline Total & & 1.6 & 23.7 & 42.3 & 32.4 & 2.2 & 27.0 & 42.6 & 28.2 \\
\hline
\end{tabular}

Abbreviation: $M C H$ maternal and child health

we weighted the data according to the sampling proportions of each region.

This survey found that $5.5 \mathrm{MCH}$ workers per 10,000 population were available in 2010. The National Health and Family Planning Commission of the People's Republic of China recommended that the $\mathrm{MCH}$ human resources to population allocation standard should be 1:10,000 in general, 1: 5,000 in less populated areas and 1: 15,000 in populated areas respectively [14]. According to this threshold, our findings suggest that the Chinese $\mathrm{MCH}$ human resources in 2010 were sufficient. However, China is a large and unevenly developing country, a rough conclusion of "enough $\mathrm{MCH}$ human resources" is apparently inappropriate, the situation may be different or even inverse in poor rural areas. However, detailed $\mathrm{MCH}$ human resource information at provincial level could not be estimated in this study because of our study design limiting our ability to examine inequities across these levels. Further studies exploring the difference of $\mathrm{MCH}$ human resources among rural, urban, populated, and less populated areas should be conducted and new $\mathrm{MCH}$ human resource thresholds for regions with different population density and developing levels should also be set by the policy makers to suit the different situation in different areas.
This study revealed the uneven distribution of both the quantity and capacity of the $\mathrm{MCH}$ human resources. This situation is incompatible with the national primary health care policy, which recommends that basic clinical and preventive care services and the corresponding human resources should evenly distribute in all levels of health institutions and not concentrated only in higher level general hospitals. Therefore measures should be introduced to allocate more $\mathrm{MCH}$ professionals in lower level institutions and in lessdeveloped areas. Motivating and encouraging policies such as reasonable remuneration and corresponding reward systems should be developed. In addition, only recruiting new professionals cannot solve the problem but sometimes may result in a waste of human resources, several measurements, such as further training, effective working arrangement, etc. can be taken to improve current workers' skills.

There are some limitations in this study. The International Standard Classification of Occupations (ISCO) was not adopted in this study. $\mathrm{MCH}$ human resources were classified based on the types of $\mathrm{MCH}$ service activities, so there might be some difficulties to conduct external comparison with other similar research results in other countries, and internal comparison 
Table 7 Proportions of the MCH workers who can deliver or conduct cardiopulmonary resuscitation of different institutions in the three regions

\begin{tabular}{|c|c|c|c|c|c|c|}
\hline \multirow[b]{2}{*}{ Area } & \multirow[b]{2}{*}{ Type of MCH-related institutions } & \multicolumn{3}{|c|}{$\begin{array}{l}\text { Proportion of women's workers } \\
\text { who can do (\%) }\end{array}$} & \multicolumn{2}{|c|}{$\begin{array}{l}\text { Proportion of conducting cardiopulmonary } \\
\text { resuscitation (\%) }\end{array}$} \\
\hline & & Cesarean & $\begin{array}{l}\text { Forceps } \\
\text { Delivery }\end{array}$ & $\begin{array}{l}\text { Vacuum extraction } \\
\text { delivery }\end{array}$ & $\begin{array}{l}\text { Women's health } \\
\text { workers }\end{array}$ & $\begin{array}{l}\text { Children's health } \\
\text { workers }\end{array}$ \\
\hline \multirow[t]{6}{*}{ East } & General hospital & 48.8 & 47.1 & 57.4 & 91.2 & 94.0 \\
\hline & Specialized MCH institution & 43.7 & 43.0 & 48.2 & 68.2 & 66.8 \\
\hline & Township health center/Community health center & 32.3 & 37.4 & 51.9 & 80.0 & 75.9 \\
\hline & Family planning service station & 45.5 & 47.4 & 64.9 & 97.5 & 100.0 \\
\hline & Others & 10.0 & 15.5 & 32.0 & 71.9 & 89.9 \\
\hline & Subtotal & 41.8 & 42.6 & 53.5 & 82.5 & 82.9 \\
\hline \multirow[t]{6}{*}{ Central } & General hospital & 55.9 & 56.4 & 61.5 & 86.7 & 90.3 \\
\hline & Specialized MCH institution & 46.3 & 46.9 & 50.3 & 86.4 & 89.3 \\
\hline & Township health center/Community health center & 40.5 & 41.4 & 55.0 & 83.1 & 79.0 \\
\hline & Family planning service station & 51.6 & 53.8 & 54.4 & 74.0 & 100.0 \\
\hline & Others & 42.5 & 42.5 & 42.5 & 62.5 & 55.2 \\
\hline & Subtotal & 46.8 & 47.5 & 55.9 & 84.5 & 84.1 \\
\hline \multirow[t]{6}{*}{ West } & General hospital & 44.5 & 47.6 & 52.3 & 94.8 & 96.0 \\
\hline & Specialized MCH institution & 45.0 & 47.4 & 53.7 & 82.7 & 74.3 \\
\hline & Township health center/Community health center & 25.0 & 32.0 & 41.4 & 82.0 & 74.5 \\
\hline & Family planning service station & 6.4 & 3.8 & 5.1 & 23.1 & 100.0 \\
\hline & Others & 12.5 & 12.5 & 25.0 & 37.5 & 33.3 \\
\hline & Subtotal & 37.7 & 42.0 & 48.3 & 88.0 & 87.5 \\
\hline \multirow[t]{5}{*}{ Total } & General hospital & 48.8 & 49.6 & 56.2 & 91.5 & 94.4 \\
\hline & Specialized MCH institution & 45.0 & 45.6 & 50.3 & 78.9 & 78.4 \\
\hline & Township health center/Community health center & 33.7 & 37.5 & 50.3 & 81.8 & 76.7 \\
\hline & Family planning service station & 38.8 & 39.9 & 41.9 & 63.1 & 100.0 \\
\hline & Others & 28.1 & 29.4 & 36.2 & 59.8 & 54.9 \\
\hline Total & & 42.2 & 44.1 & 52.6 & 85.0 & 85.1 \\
\hline
\end{tabular}

Abbreviation: $\mathrm{MCH}$ maternal and child health

among different health professions, such as between nurses and midwives. The three indicators for representing $\mathrm{MCH}$ capacity provided an opportunity to have a glance of the overall capacity of $\mathrm{MCH}$ human resources, and different distribution among different developinglevel regions and institutions. However, it's also difficult to compare between different professional groups (such as, doctors vs. nurses) because all professionals were mixed in the analysis, which also make it hard to judge the overall capacity of $\mathrm{MCH}$ human resources because of its limited external comparability and the lack of national $\mathrm{MCH}$ service capacity regulation or estimation thresholds.

According to the development plan for women and children (2011-2020), the Chinese government put an emphasis on expanding the $\mathrm{MCH}$ human resources [19], however, based on the results of our study, adding new
$\mathrm{MCH}$ workers is not a solution to the $\mathrm{MCH}$ human resource situation, more investigations on $\mathrm{MCH}$ human resources should be taken to provide useful and detailed evidence-based information for policy makers to accelerate the evenly $\mathrm{MCH}$ development in China.

\section{Conclusions}

The MCH human resources in China are not evenly distributed among the different institutions and regions, and around $30 \%$ of $\mathrm{MCH}$ workers have only a highschool degree or lower. Similar is the situation for the whole health workforce in China [20]. Therefore, more workers with higher education degrees need to be reallocated to improve the $\mathrm{MCH}$ services in China.

\section{Appendix 1}

Weighting Method 
Table 8 Proportions of MCH workers who can deliver or conduct cardiopulmonary resuscitation of different location levels

\begin{tabular}{|c|c|c|c|c|c|c|}
\hline \multirow[b]{2}{*}{ Area } & \multirow[b]{2}{*}{$\begin{array}{l}\text { Level of medical and health } \\
\text { care units }\end{array}$} & \multicolumn{3}{|c|}{$\begin{array}{l}\text { Proportion of women's workers } \\
\text { who can do (\%) }\end{array}$} & \multicolumn{2}{|c|}{$\begin{array}{l}\text { Proportion of conducting cardiopulmonary } \\
\text { resuscitation (\%) }\end{array}$} \\
\hline & & Cesarean & Forceps Delivery & Vacuum extraction delivery & Women's health workers & Children's health workers \\
\hline \multirow[t]{5}{*}{ East } & Province level & 46.7 & 35.7 & 43.9 & 96.6 & 99.4 \\
\hline & Prefectural level & 46.4 & 41.0 & 54.3 & 81.3 & 83.9 \\
\hline & County level & 46.7 & 46.9 & 54.7 & 84.0 & 85.1 \\
\hline & Township level & 33.8 & 38.5 & 53.0 & 80.2 & 75.8 \\
\hline & Subtotal & 41.6 & 42.5 & 53.6 & 82.6 & 82.9 \\
\hline \multirow[t]{5}{*}{ Central } & Province level & 61.5 & 69.2 & 69.2 & 95.0 & 100.0 \\
\hline & Prefectural level & 42.6 & 45.4 & 48.2 & 92.8 & 93.1 \\
\hline & County level & 55.0 & 54.8 & 59.3 & 83.7 & 88.4 \\
\hline & Township level & 40.8 & 41.6 & 54.9 & 82.8 & 78.8 \\
\hline & Subtotal & 46.8 & 47.5 & 55.8 & 84.5 & 84.0 \\
\hline \multirow[t]{5}{*}{ West } & Province level & 40.2 & 49.6 & 51.9 & 99.2 & 97.8 \\
\hline & Prefectural level & 50.3 & 49.6 & 55.6 & 94.8 & 97.2 \\
\hline & County level & 41.2 & 43.4 & 49.7 & 85.3 & 81.0 \\
\hline & Township level & 25.3 & 31.8 & 40.7 & 81.3 & 74.6 \\
\hline & Subtotal & 37.7 & 42.0 & 48.3 & 88.0 & 87.5 \\
\hline \multirow[t]{4}{*}{ Total } & Province level & 41.6 & 47.4 & 50.7 & 98.6 & 98.4 \\
\hline & Prefectural level & 47.1 & 46.3 & 53.0 & 90.8 & 94.4 \\
\hline & County level & 48.2 & 48.8 & 54.9 & 84.2 & 85.0 \\
\hline & Township level & 34.5 & 38.0 & 50.5 & 81.6 & 76.6 \\
\hline Total & & 42.1 & 44.1 & 52.6 & 85.0 & 85.1 \\
\hline
\end{tabular}

Abbreviation: $\mathrm{MCH}$ maternal and child health

Because the sampling unit is districts/cities at prefectural level (including prefectural cities in province and districts in municipalities), so the weights are mainly based on the proportion of sampled districts/cities:

For Beijing, there are 16 districts, and we selected 4, so the weight was $16 / 4=4$

For Tianjin, there are 16 districts, and we selected 4 , so the weight was $16 / 4=4$

For Shanghai, there are 15 districts, and we selected 4, so the weight was $18 / 4=4.5$

For Chongqing, there are 15 districts, and we selected 4, so the weight was $40 / 4=10$

For all provinces and autonomous regions, there are total 332 prefectural level cities, from which we select 28 , so the weight should be $332 / 28=11.8$, but we decreased it to 11 by experts consulting and research experience.

Finally, by using the weights, the results turned out to be good, the sum of the weighted populations in the sample districts/cities was very near (with only $5.7 \%$ errors) to the actual population number (China census 2010).

\section{Abbreviations}

MCH: maternal and child health; MDG: Millennium Development Goal.
Competing interests

The authors declare that they have no competing interests.

\section{Authors' contributions}

LA and SFG conceptualised the study design. PGS and ZHR prepared the first draft of the manuscript. ZHR, ET, PGS and LA contributed to writing and interpretation of findings. All three authors contributed to the reference search, read and approved the final manuscript.

\section{Acknowledgements}

All authors thank the experts for their helps in improving our survey instruments, and the workers from the MCH-related institutions in the sample areas for their contribution in collecting data. We express our sincere thanks to UNICEF for their supports.

\section{Author details}

${ }^{1}$ Department of Child, Adolescent and Women's Health, School of Public Health, Peking University, Beijing, China. ${ }^{2}$ Centre for Population Health Sciences, the University of Edinburgh, Edinburgh, UK. ${ }^{3}$ UNICEF China, Beijing, China.

Received: 28 January 2015 Accepted: 14 December 2015 Published online: 16 December 2015

\section{References}

1. Ministry of Health, People's Republic of China. Report on Women and Children's Health Development in China. China; 2011.

2. World Health Organization. The World Health Report 2005: Make every mother and child count. Geneva: World Health Organization, 2005.

3. Bryce J, Black RE, Victora CG. Millennium Development Goals 4 and 5: progress and challenges. BMC Med. 2013;11:225. 
4. Bhutta ZA, Chopra M, Axelson H, Berman P, Boerma T, Bryce J, et al. Countdown to 2015 decade report (2000-10): taking stock of maternal, newborn, and child survival. The Lancet. 2010;375:2032-44.

5. The State Council Information Office of the People's Republic of China. Medical and Health Services in China: white paper. [http://www.chinaembassy.org/eng/zt/bps/t1001641.htm].

6. Ministry of Foreign Affairs of the People's Republic of China, United Nations System in China. China's Progress Towards the Millennium Development Goals 2013 Report. China; 2013.

7. Meng Q, Xu L, Zhang Y, Qian J, Cai M, Xin Y, et al. Trends in access to health services and financial protection in China between 2003 and 2011: a cross-sectional study. The Lancet. 2012;379:805-14.

8. Strand MA, Fischer PR. An appraisal of China's progress toward the Millennium Development Goals as they relate to children. Paediatr Int Child Health. 2013:34:156-164.

9. Lozano R, Wang H, Foreman KJ, Rajaratnam JK, Naghavi M, Marcus JR, et al. Progress towards Millennium Development Goals 4 and 5 on maternal and child mortality: an updated systematic analysis. The Lancet. 2011;378:1139-65.

10. World Health Organization. The world health report: 2006: working together for health. Geneva: World Health Organization, 2006.

11. Liese B, Dussault $\mathrm{G}$. The state of the health workforce in sub-Saharan Africa: evidence of crisis and analysis of contributing factors. Africa Region: World Bank; 2004.

12. Khan KS, Wojdyla D, Say L, Gülmezoglu AM, Van Look PF. WHO analysis of causes of maternal death: a systematic review. The Lancet. 2006;367:1066-74.

13. Hesketh T, Zhu Wei X. Health in China: maternal and child health in China. BMJ. 1997;314:1898.

14. Chinese Center for Disease control and Prevention: management regulation for MCH institutions [in Chinese]. [http://www.chinacdc.cn/n272442/ n272530/n273736/n273872/n321585/36150.html].

15. China health human resource: Introduction of health qualification certificate examinations [in Chinese]. [http://www.21wecan.com/rcpj/zcj/ksjs/ f049f96ab9aba947a0eb593ced1760a8.html].

16. Chinese Center for Disease Control and Prevention: National survey of maternal and child health services begin. [http://www.chinacdc.cn/zxdt/ 201111/t20111107_54660.htm].

17. Xi'an Technology Resources Market: Xi'an health bureau's announcement about national survey of maternal and child health services. [http://news. xatrm.com/gov/announc/xasrmzfwtz/ B123011C9C05428CE040007F01003A5C.html].

18. Yanqiu G, Ronsmans $\mathrm{C}$, Lin A. Time trends and regional differences in maternal mortality in China from 2000 to 2005. Bull World Health Organ. 2009:87:913-20.

19. The Central People's Government of the People' Republic of China: The announcement about the outline for the development of Chinese women and children [http://www.gov.cn/zwgk/2011-08/08/content_1920457.htm]

20. Anand S, Fan VY, Zhang J, Zhang L, Ke Y, Dong Z, et al. China's human resources for health: quantity, quality, and distribution. The Lancet. 2008;372:1774-81.

\section{Submit your next manuscript to BioMed Central and we will help you at every step:}

- We accept pre-submission inquiries

- Our selector tool helps you to find the most relevant journal

- We provide round the clock customer support

- Convenient online submission

- Thorough peer review

- Inclusion in PubMed and all major indexing services

- Maximum visibility for your research

Submit your manuscript at www.biomedcentral.com/submit

Biomed Central 